\title{
Open the Windows of Communication: Promoting Interpersonal and Group Interactions Using Blogs in Higher Education
}

\author{
Ina Blau, Nili Mor, and Tami Neuthal \\ Open University of Israel, Ra'anana, Israel
}

ina.blau@gmail.com; nilimo@openu.ac.il; tamine@openu.ac.il

\begin{abstract}
Using educational blogs enriches online learning by creating a peer dialogue in the form of a reader response or a peer-blogger-peer feedback sequence. The present study explores interpersonal and group interactions in an academic course using blogs. The findings show that, as predicted by the theory of electronic propinquity (TEP), the feeling of nearness transmitted by students via blog posts interacted with different behavior variables (i.e., choosing post content-type, calling for feedback, responding to peers' comments) and positively affected students' interpersonal online interactions. Furthermore, bloggers' ongoing responses to readers' comments promote additional peers' feedback. According to the hypothesis, private authorship in personal blogs affected group interaction patterns in comparison to multi-authored wikis. While educational blogs promoted communication among all course students, wiki interactions were affected by student offline former acquaintance and social contact.

The present study findings suggest some recommendations concerning the use of educational blogs in order to encourage interactivity among students: (1) projecting nearness to audience, (2) sharing work experiences, feelings related to learning or personal experiences, and especially sharing student thoughts, rather than providing information, (3) calling for feedback, and (4) responding to peers' comments.
\end{abstract}

Keywords: interpersonal and group online interaction, comments, educational blog, wiki, nearness, immediacy, electronic propinquity, social presence

\section{Introduction}

Online learning environments based on student-instructor and student-student interactions are widely used in higher education. Active online student interaction is a significant predictor of per-

Material published as part of this publication, either on-line or in print, is copyrighted by the Informing Science Institute. Permission to make digital or paper copy of part or all of these works for personal or classroom use is granted without fee provided that the copies are not made or distributed for profit or commercial advantage AND that copies 1) bear this notice in full and 2) give the full citation on the first page. It is permissible to abstract these works so long as credit is given. To copy in all other cases or to republish or to post on a server or to redistribute to lists requires specific permission and payment of a fee. Contact Publisher@InformingScience.org to request redistribution permission. ceived learning (Rovai \& Barnum, 2003), learning outcomes, and student satisfaction (Brady, 2004). Interactivity is defined as "a process-related variable concerning responsiveness" (Rafaeli \& Ariel, 2007, p. 84). Research indicates that "with effective e-learning technologies we can create active, engaged, collaborative, and inquiry-based learning opportunities" (Wishart \& Guy, 2009,

\section{Editor: Alex Koohang}

An earlier, shorter version of this paper was presented at the Chais conference 2009, in Raanana, Israel, and included in Y. Eshet-Alkalai, A. Caspi, S. Eden, N. Geri, \& Y. Yair (Eds.), Proceedings of the Chais conference on instructional technologies research 2009: Learning in the technological era. Raanana: The Open University of Israel. http://www.openu.ac.il/research center eng/conferences.html 
p.142). Learners' self-reflection and scaffolding are necessary elements for the design of effective learning activities (Koohang, Riley, Smith, \& Schreurs, 2008). The blogosphere is a powerful learning space that promotes reflective thinking (Xie, Ke \& Sharma, 2008), improves student achievement (Palmer, Holt \& Bray, 2008), and offers the opportunity to interact with others and learn in a natural environment as part of everyday life (Ladyshewsky \& Gardner, 2008; Ševelj, 2006). Unlike cell phone text messaging (SMS), which successfully supports one-way interactions between instructor and students in the context of higher education (DuVall, Powell, Hodge, \& Ellis, 2007), educational blogs are more focused on student-student two-way communication. Interpersonal interaction patterns between authors and readers in educational blogs differ from those in the global blogosphere (Duarte, Mattos, Bestavros, Almeida, \& Almeida, 2006) because educational blogs are less visible, written by ordinary people mainly for the relatively small audience of a specific network (Nardi, Schiano \& Gumbrecht, 2004).

Educational blogs are sometimes used as "online diaries", where students write about their own experiences or share their ideas related to course topics (Davi, Frydenberg \& Gulati, 2007). This kind of educational blogging is both a student-centered and peer-focused activity (Chiddo, 2006; Glogoff, 2005) which maintains two kinds of student interaction: intra-personal dialogue as well as inter-personal interaction (Gorsky, Caspi \& Chajut, 2008). On the intra-personal level, blogging, which allows thinking by writing (Nardi et al., 2004), can clarify thoughts or emotions (McKenzie, 2008) and be a beneficial activity contributing to personal and professional development (Felix, 2008). On the inter-personal level, communication with others is a prevalent motivation for adult blog writing in general (Miura \& Yamashita, 2007) and in adult educational blog writing in particular (Windham, 2007). A peer dialogue via blogs is created by posting entries and receiving reader comments or in the form of a peer-blogger-peer feedback sequence (Huffaker, 2005; Kim, 2008). Questioning and challenging each other's thinking leads to deep, meaningful interactions and learning (Poling, 2005). Students enjoy an opportunity to open the windows of communication - reading their classmates' postings and having classmates comment on their own writing (Blackston, Spiri, \& Naganuma, 2007; Windham, 2007). Comments are important for the bloggers' experience (Gumbrecht, 2004; Miura \& Yamashita, 2007; Trevino, 2005). The need for receiving comments and, more generally, the need for an audience in the blogosphere and for the community of classmates vary between students (Kerawalla, Minocha, Kirkuk, \&Conole, 2009). However, positive feedback, either from peers or a teacher, increases student willingness to write in the educational blog (Levenberg \& Gorsky, 2008; Pinkman, 2005).

Some theoretical approaches use different terms explaining the similar effect of nearness on interpersonal interaction. Predating the Internet, Korzenny (1978) offered the theory of electronic propinquity (TEP), which is a general theory of mediated communication. Electronic propinquity is "electronic proximity, electronic nearness, or electronic presence" (Korzenny, 1978, p. 7). Recently it was defined as a "psychological feeling of nearness that communicators experience using different communication channels" (Walther \& Bazarova, 2008, p. 624). Walther and Bazarova validated TEP in computer mediated communication and extended the theory for text-based interaction, in addition to face-to-face and voice- or video-conferencing communication. Original TEP predicted that mutual directionality of communication increases electronic propinquity, but this hypothesis was not validated in Walther and Bazarova's study.

The concept of immediacy was defined by Mehrabian as "those communication behaviors that enhance closeness to and nonverbal interaction with another" (Mehrabian, 1969, p. 203). The positive impact of immediacy on learning process and outcomes has been widely tested in offline classrooms (see Witt, Wheeless, \& Allen, 2004). In an online text-based environment, social presence that is based on the concept of immediacy (Rourke, Anderson, Garrison, \& Archer, 1999) was described as the ability of learners to project themselves socially and emotionally as real people in an online learning community (Garrison, 2007). However, this approach refers to 
actual social presence (i.e., a number of self-projection indicators), which may be different from the level of social presence perceived by readers (Blau \& Caspi, 2007) - the feeling of nearness. It was found that perceived social presence in academic online environments positively related to perceived learning (Caspi \& Blau, 2008), student participation (Gorsky \& Blau, 2009), and satisfaction (Kang, Kim, \& Park, 2008; Shea, Pickett, \& Pelt, 2003).

As can be seen from this brief literature review, different theoretical approaches (from various fields such as psychology, media research, and e-learning) refer to similar effects using a different terminology (i.e. electronic propinquity / immediacy / perceived social presence). Following Walther and Bazarova's (2008) definition presented above, in this study we use the more neutral term - the feeling of nearness - to describe this effect.

To the best of our knowledge, no empirical testing of the relation between the feeling of nearness and interactivity in a blog environment has been conducted, but descriptions of different language use in different blog types may indicate the existence of such relations. The majority of blogs fall within the following two general types: informational blogs in the tradition of the newspaper column, and personal diaries that describe people's personal thoughts, day-to-day experiences, and feelings (Chesher, 2005; Herring et al., 2005). Informational blogs use a more formal language, while personal diary language is more informal and transmits nearness to the audience (Herring \& Paolillo, 2006).

A few studies explore authorship issues in asynchronous educational tools (see Lankshear \& Knobel, 2006; Warschauer \& Grimes, 2007). It was found that students who used a shared blog were less interested in blogging compared to students who used a personal blog (Kim, 2008). A personal blog is a private space, a "home" and a personal property of the individual student who has control and ownership over the discourse (Ducate \& Lomicka, 2005; Hurlburt, 2008; Lamshed, Berry \& Armstrong, 2002). It was found that online publishing (i.e. a blogger's activity) results in high levels of students' ownership, whereas collaborative editing (i.e. a wiki editor's activity) results in low levels of psychological ownership (Blau \& Caspi, 2009). Authorship in personal blogs is strongly identified with the writer through his nickname in each blog entry and information in the profile section (Chesher, 2005), while wiki entries are collaborative and multiauthored (Warschauer \& Grimes, 2007).

The purpose of this study was to explore interpersonal and group interactions using blogs. Specifically, this study investigated the relations between the feeling of nearness (electronic propinquity / immediacy / perceived social presence) perceived via posts and inter-personal bloggerreader interactions in educational blogs. In addition, this study compared peer group interactions in educational blogs to wiki group interactions. Based on TEP prediction, we hypothesized that (1) the feeling of nearness would positively influence interpersonal interactivity; (2) private authorship in personal blogs and multi-authored wikis would arouse different group interaction patterns.

\section{Method}

\section{Participants}

The participants were 25 graduate students ( $76 \%$ women) enrolled in the spring 2008 semester of a graduate course in the field of Educational Technology at the Open University of Israel. The participants' ages ranged from 27 to 53 . 


\section{Instruments and Procedure}

The participants studied in a blended learning environment including face-to-face meetings in two groups with two different instructors (there were no offline meetings with students of the other group) and online communication between course students, which was moderated by both instructors. As a part of online learning activities with minimum involvement of moderators and without academic credit, the students wrote personal blogs using Google's Blogger

(https://www.blogger.com/) platform as well as group weekly summaries using a wiki environment.

During the semester the participants wrote 133 posts and 209 comments. The feeling of nearness was measured as perceived post nearness versus distance by checking if a post included $(\mathrm{N}=101$, $75.9 \%$ ) or excluded expressions of warmth and confidence, humor, and self-disclosure. Following Herring et al.'s (2005) observation, student post contents were categorized and divided into four content groups: posts sharing (1) information, $\mathrm{N}=28$, (2) thoughts, $\mathrm{N}=26$, (3) work experiences, $\mathrm{N}=33$, and (4) feelings related to learning or personal experiences, $\mathrm{N}=46$. Feedback promoting was measured by checking if a post included ( $\mathrm{N}=32,24 \%)$ or excluded phrases like "I'd love to know your opinion", "what do you think?", "is someone feeling like me?" etc.

The present study examined actual (realization of) interactivity which is different from perceived or expected interactivity (Rafaeli \& Ariel, 2007). Only a few students in this study used blog expressions of social relations (Furukawa, Ishizuka, Matsuo, Ohmukai, \& Uchiyama, 2007; Marlow, 2004) such as the trackback function (citation hyperlinks) and a blogroll (a list of links to other blogs on the front page). Therefore only peers' and bloggers' own comments were consid-

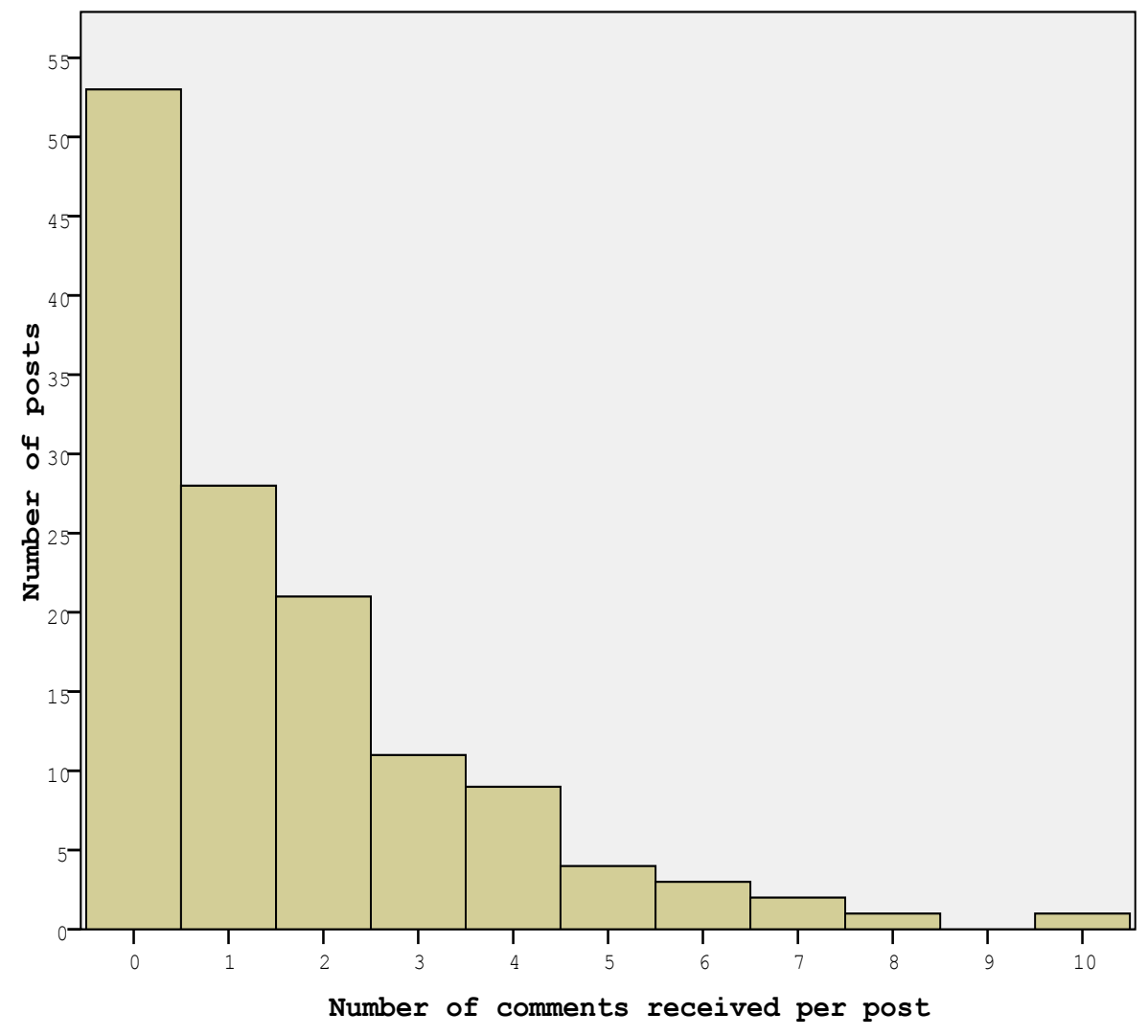

Figure 1: Distribution of comments received 
ered as interpersonal interaction measures. All educational blogs in the present study received peer feedback, while only $28 \%$ of global community blogs contain comments from readers (Mishne \& Glance, 2006). The number of comments per post found in this study (Range: 0-10, Median: 1, Mean: 1.57, SD: 1.94, Skewness: 1.64) was also higher than the average of 0.3 comments per post in the entire blogosphere (Herring, Scheidt, Bonus, \& Wright, 2004). Twenty four $(18 \%)$ posts in the present study contained blogger's own response to peers' comments (Range: 05, Median: 0, Mean: 0.3, SD: 0.79, Skewness: 3.47). The figures show the distributions of the variables: number of comments per post (Figure 1) and number of blogger's own responses per post (Figure 2). As can be seen, the distribution of both variables is skewed. Raban and Rabin (in press) argued that in order to perform parametric statistical tests (based on assumption of normal or close to normal distribution) with such asymmetrical, "long tail" distributed variables, some kind of transformation is needed. According to the results of a curve estimation procedure, we performed a logarithmic transformation (base 10) of these two variables before the data analysis.

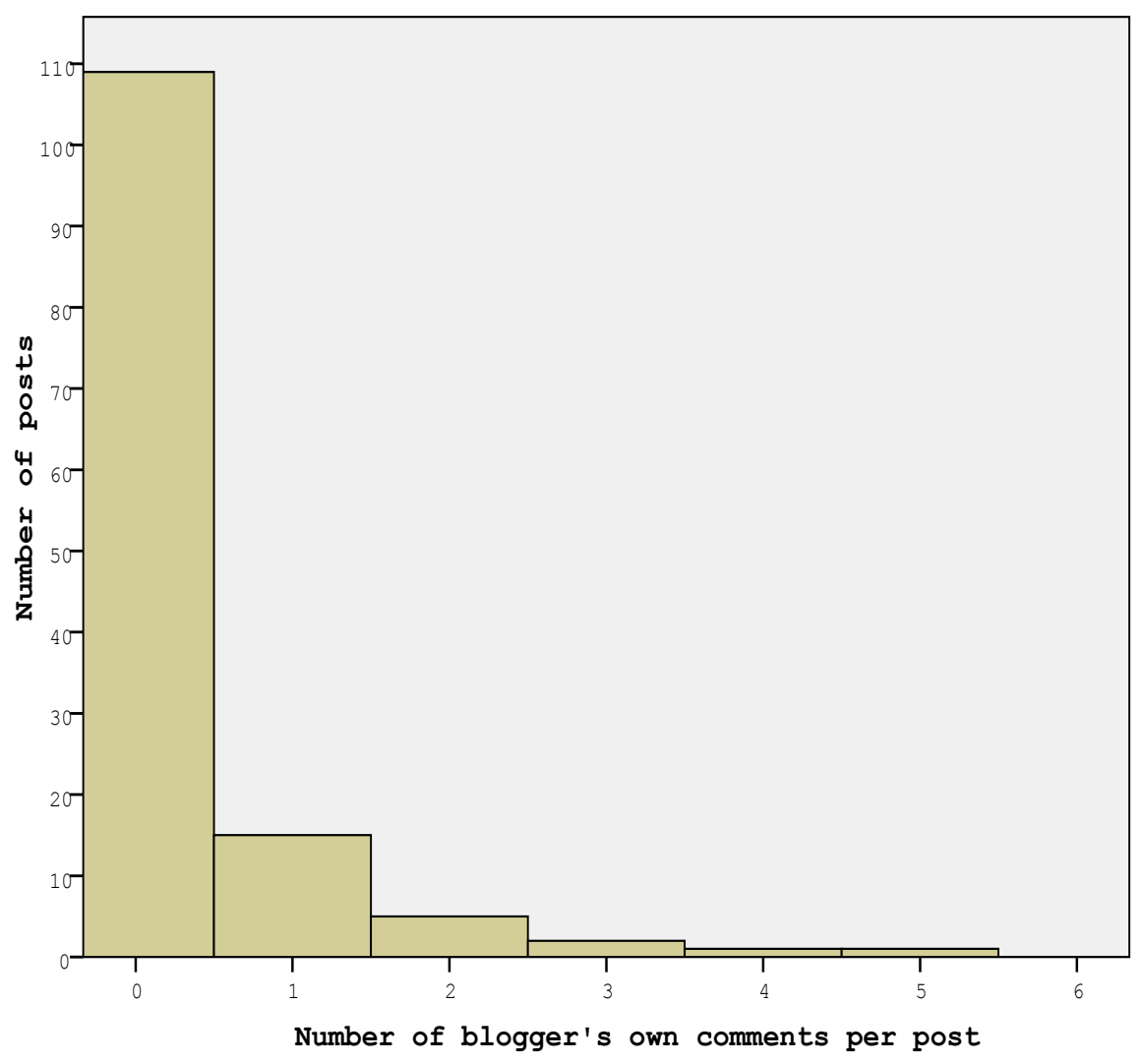

Figure 2: Distribution of bloggers' own comments

Group interactions using blogs were measured separately as the number of comments received from peers studying in the same or in the other offline group. Group interactions using wiki were measured as the number of students choosing partners for shared weekly summary writing from their own or from the other offline group. 


\section{Results}

\section{Interpersonal Blog Interactions}

The feeling of nearness affected the amount of interactivity; the posts estimated as near (Mean: 1.80) received significantly more comments compared to posts perceived as distant (Mean: 0.84; $t(131)=3.13, p<.001, d=.50)$.

Table 1 shows descriptive statistics of comments received per post in different content categories.

Table 1: Means, $S D$ and $S E$ of comments received per post in different content types

\begin{tabular}{lcccc}
\hline \multicolumn{1}{c}{ Post content type } & $\boldsymbol{N}$ & $\boldsymbol{M}$ & $\boldsymbol{S D}$ & $\boldsymbol{S} \boldsymbol{E}$ \\
\hline Information & 28 & 0.25 & 0.70 & 0.13 \\
Thoughts & 26 & 2.50 & 2.40 & 0.47 \\
Work experiences & 33 & 1.70 & 1.69 & 0.29 \\
Feelings & 46 & 1.76 & 1.97 & 0.29 \\
\hline
\end{tabular}

The one-way ANOVA test showed a statistically significant effect of post content on the number of comments received, $F(3,129)=15.3, p<.001$. Subsequent tests showed that compared to other content categories informational posts received a significantly smaller number of comments (the effect size was large), while posts which shared student thoughts received a significantly larger number of comments (the effect size was medium). Table 2 summarizes these results.

Table 2: Comparisons of content effect on number of comments: Post-hoc tests

\begin{tabular}{lcl}
\hline Post content type comparisons & \multicolumn{1}{c}{$\boldsymbol{p}$} & Effect size \\
\hline Information - Thoughts & $<.001$ & $d=2.19$ \\
Information - Work experiences & $<.001$ & $d=1.18$ \\
Information - Feelings & $<.001$ & $d=.1 .30$ \\
Thoughts - Work experiences & $<.05$ & $d=.55$ \\
Thoughts - Feelings & $<.05$ & $d=.50$ \\
\hline
\end{tabular}

Posts which included feedback promoting (Mean: 2.25 ) received significantly more comments in comparison with posts that excluded feedback promoting (Mean: 1.36; $t(131)=4.44, p<.001, d$ $=.49$ ). The blogger's own comments highly predict the number of peers' comments, $F(131,1)=$ $136.59, p<.001, R^{2}=.51, \beta=.71$.

Other variables, such as a relevance of post to course topics, frequency of posting, and post length, did not affect interactivity. Since students were not limited to writing solely about course issues, only 36 posts $(27.1 \%)$ directly discussed course topics or learning activities. The analysis showed that the posts discussing course issues did not receive more comments compared to less relevant posts, $p>.90$. The frequency of posting in each blog may characterize the level of blogger's engagement (Duarte et al., 2006). In contrast with previous studies, which showed a correlation between a self-reported average weekly number of posts made and comments received in the entire blogosphere (see Marlow, 2006), interactions in educational settings in this study were not affected by the actual posting frequency or by a post length. 
As suggested by Blau, Mor, and Neuthal (2009), when peer interactions are important to students, they use different ways of promoting interactions and maintaining communication. An ANOVA test was performed for further investigation of the effect of different blogger's behaviors promoting interactivity on peers' comments and their possible interactions with the feeling of nearness. Table 3 summarizes this data. The influence of nearness, content type, feedback promotion, and blogger's own feedback explained $58 \%$ of variance in peers' comments, $F(125,7)=28.34, p<$ .001 .

Table 3: The influence of nearness, content type, feedback promotion, and blogger's own feedback on peers' comments - ANOVA

\begin{tabular}{lccc}
\hline \multicolumn{1}{c}{ Effects and interactions } & $\boldsymbol{F}$ & $\boldsymbol{d f}$ & $\boldsymbol{p}$ \\
\hline Nearness & 0.68 & 1 & n.s. \\
Content type & 3.28 & 3 & $<.05$ \\
Feedback promotion & 0.45 & 1 & n.s. \\
Blogger's own feedback & 54.33 & 1 & $<.001$ \\
Nearness * Blogger's own feedback & 2.95 & 1 & $<.05$ \\
\hline
\end{tabular}

The "*" refers to interactions

Since the influence of blogger's own feedback explained a large percentage of variance in peers' comments (partial $\eta^{2}=.30$ ) and showed statistically significant interaction with the feeling of nearness, an additional ANOVA test was performed in order to explore the possible mediation of blogger's response on peers' comments. The influence of nearness, content type, feedback promotion, and their interactions explained $19 \%$ of variance in blogger's response to peers' comments, $F(123,9)=3.26, p<.001$. Table 4 shows the main effects and interactions between the variables.

Table 4: The influence of nearness, content type, feedback promotion, and their interactions on blogger's own feedback - ANOVA

\begin{tabular}{lccc}
\hline \multicolumn{1}{c}{ Effects and interactions } & $\boldsymbol{F}$ & $\boldsymbol{d f}$ & $\boldsymbol{p}$ \\
\hline Nearness & 0.81 & 1 & n.s \\
Content type & 3.16 & 3 & $<.05$ \\
Feedback promotion & 0.05 & 1 & n.s. \\
Nearness * Content type & 2.96 & 3 & $<.05$ \\
Nearness * Feedback promotion & 2.87 & 1 & $<.05$ \\
\hline
\end{tabular}

\section{Comparing Group Interactions through Blogs and Wikis}

The comparison of group interactions using blogs and wiki showed the differences between these tools. Statistically significantly more students, $\chi^{2}(1)=10.7, p<.01$, chose to write wiki group weekly summaries with others known from face-to-face interaction (22), compared to students who chose editing a wiki summary with unknown students from the other offline group. However, group interaction in blogs was not related to offline groups; there was no statistically significant difference between receiving comments from the blogger's own group and from students who learn in a different offline group, $p>.70$. 


\section{Discussion}

The purpose of this study was to explore interpersonal and group interactions using educational blogs and comparing them to educational wikis. Our first research question referred to interpersonal interaction through educational blogs. As hypothesized, based on the theory of electronic propinquity, interpersonal interactions were affected by the feeling of nearness. The posts estimated as near received significantly more comments compared to posts which were perceived as distant. Nearness in bloggers' posts also affected the interactivity in interaction with different blogger behaviors, such as choosing certain post content type, including phrases promoting feedback in a post, and responding to peers' comments.

The results indicated the importance of these interactivity-promoting behaviors. A blogger's own feedback in the comment section had a strong direct impact as well as interacted with the feeling of nearness. In addition, blogger's own comments moderated the influence of other behavior variables - feedback promotion and choosing a post content-type. The results also showed that choosing an appropriate post content influenced directly on peer comments, as well as on blogger's own feedback. Schmidt (2007) claimed that speaking in one's own personal voice and being open for dialogue rather than engaging in one-way communication are core elements readers expect from blog communication, in either personal online diaries or informational blogs. Kim's (2008) study recommends instructors and students to seek relevant information from other websites and share it on a blog. The present study findings indicate that students had difficulty in preserving a personal voice in information providing, thus informational posts mostly resulted in one-way communication. On the other hand, sharing work experiences, learning, and personal feelings, and especially sharing student thoughts, significantly enhanced a dialog with peers.

In summary, the feeling of nearness in interaction with an appropriate content type, with feedback promoting expressions, and with blogger's own feedback, called for peers' comments. Figure 3 presents a two phase model of promoting interactivity in educational blogs based on our findings. In the first phase (see Table 4), a blogger's response to peer comments was affected by choosing an appropriate post content-type (both directly and in interaction with the feeling of nearness), as well as by including phrases promoting feedback in posts (in interaction with the feeling of nearness). In the second phase (see Table 3), the peers' comments were influenced by the post content-type and by blogger's own comments (both directly and in interaction with the feeling of nearness).

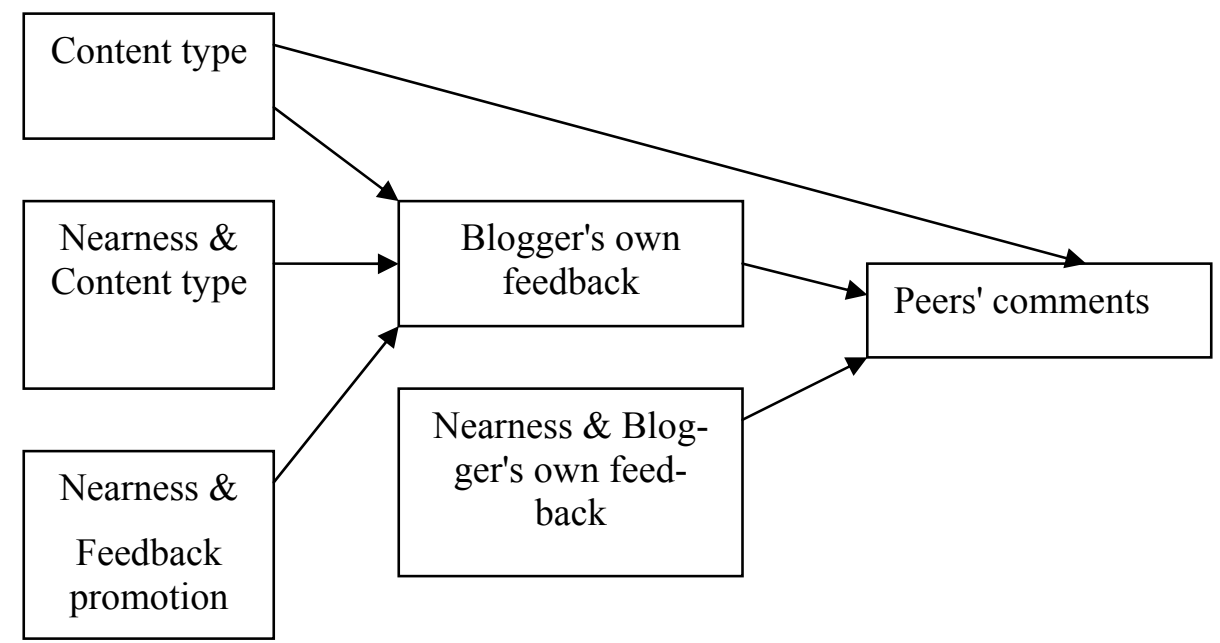

Figure 3: Model of interactivity promotion in educational blogs 
Our second research question referred to group interaction through educational blogs in comparison with group interactions through educational wikis. As hypothesized, private authorship in personal blogs and multi-authored wikis aroused different group interaction patterns. Almost all students chose to collaborate with peers with whom they were acquainted from face-to-face tutorials in the wiki task, while group interactions in blogs were not related to offline groups. As expressed by Cunningham (2005), developer of the first wiki platform, "the blogosphere is a community that might produce a work, whereas a wiki is a work that might produce a community." Blogs in the present study promoted the creation of an online learning community which included all course students, while interactions via wiki, similar to Blau and Caspi's (2008b) study, remained affected by student offline communication. Certainly it is the people who make online learning happen, not the technology (Mejias, 2005), but it seems that a medium per se still affects emotional aspects of learning, such as students' interest, learning satisfaction, and enjoyment of interaction with instructor or peers (Blau \& Caspi, 2008a).

\section{Conclusions and Implications}

The results of this study support both of the hypotheses proposed. Corresponding to TEP prediction, the feeling of nearness transmitted by students via blog posts positively affected interpersonal student interaction. The influence of nearness projected through posts on peers' comments interacted with different behavior variables (i.e. choosing post content-type, calling for feedback, responding to peers' comments). Private authorship in personal blogs affected group interaction patterns in comparison with multi-authored wikis. While educational blogs promote the creation of an online learning community that includes all course students, the interaction via wiki remains affected by student offline communication.

The study findings suggest some recommendations concerning the use of educational blogs in order to encourage student interactivity: (1) projecting nearness to the audience, (2) sharing work experiences, feelings related to learning, or personal experiences, and especially sharing student thoughts rather than providing information, (3) inviting feedback, and (4) responding to peers' comments. However, it should be taken into consideration that the model of interactivity promotion suggested in this paper is based on the analysis of posts written in a single graduate course (one semester). Further research with a larger population is needed to explore this model.

\section{References}

Blackston, B., Spiri, J., \& Naganuma, N. (2007). Blogs in English language teaching and learning: Pedagogical uses and student responses. Reflections on English Language Teaching (RELT), 6(2), 1-19. Available http://www.nus.edu.sg/celc/publications/RETL62/01 to20blackstone.pdf

Blau, I., \& Caspi, A. (2007). Social presence and participation in asynchronous discussion groups. In Y. Eshet, A. Caspi, \& Y. Yair (Eds.), Learning in the technological era (pp. 59-66). Ra'anana: The Open University of Israel [in Hebrew]. Available http://telempub.openu.ac.il/users/chais/2007/morning 2/M2 6.pdf

Blau, I., \& Caspi, A. (2008a). Do media richness and visual anonymity influence learning? A comparative study using Skype ${ }^{\mathrm{TM}}$. In Y. Eshet, A. Caspi, \& N. Geri (Eds.), Proceedings of the Chais Conference on Instructional Technologies Research 2008: Learning in the technological era (pp. 18-25). Ra'anana, Israel: Open University of Israel. Available http://telem-pub.openu.ac.il/users/chais/2008/noon/4_2.pdf

Blau, I., \& Caspi, A. (2008b). To edit? No, to recommend! Perception of collaborative learning and its quality as influenced by educational wiki entry editing. In D. Ben-Zvi (Ed.), Innovative e-learning in higher education (pp.19-23). Haifa, Israel: University of Haifa. [in Hebrew]

Blau, I., \& Caspi, A. (2009). What type of collaboration helps? Psychological ownership, perceived learning and outcome quality of collaboration using Google Docs. In Y. Eshet-Alkalai, A. Caspi, S. Eden, 
N. Geri, \& Y. Yair (Eds.), Proceedings of the Chais Conference on Instructional Technologies Research 2009:Learning in the technological era (pp.48-55). Ra'anana, Israel: Open University of Israel. Available http://telem-pub.openu.ac.il/users/chais/2009/noon/1_1.pdf

Blau, I., Mor, N., \& Neuthal, T. (2009). Interpersonal and group interactions using educational Blogs. In Y. Eshet-Alkalai, A. Caspi, S. Eden, N. Geri, \& Y. Yair (Eds.), Proceedings of the Chais Conference on Instructional Technologies Research 2009:Learning in the technological era (pp.56-64). Ra'anana, Israel: Open University of Israel. Available http://telempub.openu.ac.il/users/chais/2009/after_noon/1_1.pdf

Brady, L. (2004). The role of interactivity on the effectiveness of an educational science website for middle school students. Unpublished dissertation. Wichita State University.

Caspi, A., \& Blau, I. (2008). Online discussion groups: The relationship between social presence and perceived learning. Social Psychology of Education, 11, 323-346.

Chesher, C. (2005, May). Blogs and the crisis of authorship. Presented at the meeting of the Blogtalk Downunder, Sydney. Retrieved April 2, 2009 from http://incsub.org/blogtalk/?page id=40

Chiddo, D. A. (2006). Student-centered educational technology in the language classroom. The College of William and Mary School of Education. Retrieved April 2, 2009, from http://www.wm.edu/education/599/06projects/chiddo.pdf

Cunningham, W. (2005, October). Crucible of creativity. Keynote at the 2005 International Symposium on Wikis. San Diego, California, US. Retrieved April 2, 2009 from http://many.corante.com/archives/2005/10/17/ward_cunningham_on the_crucible_of_creativity.php

Davi, A., Frydenberg, M., \& Gulati, G. J. (2007). Blogging across the disciplines: Integrating technology to enhance liberal learning. MERLOT Journal of Online Learning and Teaching, 3(3), 222-233. Available http://jolt.merlot.org/vol3no3/frydenberg.pdf

Duarte, F., Mattos, B., Bestavros, A., Almeida, V., \& Almeida, J. (2006, March). Traffic characteristics and communication patterns in Blogosphere. Paper presented at the $1^{\text {st }}$ International Conference on Weblogs and Social Media (ICWSM'06). Boulder, Colorado, USA. Retrieved April 2, 2009 from http://www.cs.bu.edu/techreports/pdf/2006-033-blog-characterization.pdf

Ducate, L., \& Lomicka, L. (2005). Exploring the blogosphere: Use of web logs in the foreign language classroom. Foreign Language Annals, 38(3), 4-10.

DuVall, J. B., Powell, M. R., Hodge, E., \& Ellis, M. (2007). Text messaging to improve social presence in online learning. Educause Quarterly, 3, 24-28. Available http://net.educause.edu/ir/library/pdf/EQM0733.pdf

Felix, J. (2008). Edublogging: Instruction for the digital age learner. In K. McFerrin et al. (Eds.), Proceedings of Society for Information Technology and Teacher Education International Conference 2008 (pp. 3741-3748). Chesapeake, VA: AACE.

Furukawa, T., Ishizuka, M., Matsuo, Y., Ohmukai, I., \& Uchiyama, K. (2007, July). Analyzing reading behavior by blog mining. $22^{\text {nd }}$ Conference on Artificial Intelligence (AAAI-07). Retrieved April 2, 2009 from http://www.miv.t.u-tokyo.ac.jp/papers/furukawa-AAAI07.pdf

Garrison, D. R. (2007). Online community of inquiry review: Social, cognitive, and teaching presence issues. Journal of Asynchronous Learning Networks, 11(1), 61-72.

Glogoff, S. (2005). Instructional blogging: Promoting interactivity, student-centered learning, and peer input. UA Learning Technologies Center. Retrieved April 2, 2009, from http://www.elearn.arizona.edu/stuartg/resume/article.pdf

Gorsky, P., \& Blau, I. (2009). Online teaching effectiveness: A tale of two instructors. The International Review of Research in Open and Distance Learning, 10(3), 1-27. Available http://www.irrodl.org/index.php/irrodl/article/view/712/1303 
Gorsky, P., Caspi, A., \& Chajut, E. (2008). The theory of instructional dialogue: Toward a unified theory of instructional design. In R. Zheng, \& S. Pixy-Ferris (Eds.), Understanding online instructional modeling: Theories and practices (pp. 47-68). Hershey, PA: Idea Group, Inc.

Gumbrecht, M. (2004, May). Blogs as "protected space". In WWW 2004 Workshop on the Weblogging Ecosystem: Aggregation, Analysis and Dynamics, 2004, at WWW '04: The $13^{\text {th }}$ international conference on World Wide Web, 2004. Retrieved April 2, 2009, from http://www.blogpulse.com/papers/www2004gumbrecht.pdf

Herring, S. C., Kouper, I., Paolillo, J. C., Scheidt, L. A., Tyworth, M., Welsch, P., Wright, E., \& Yu, N. (2005). Conversations in the blogosphere: An analysis "from the bottom up." Proceedings of the 38th Hawaii International Conference on System Sciences- HICSS'05 (pp. 107-118). Los Alamitos, CA: IEEE Press.

Herring, S. C., \& Paolillo, J. C. (2006). Gender and genre variation in weblogs. Journal of Sociolinguistics, 10(4), 439-459.

Herring, S. C., Scheidt, L. A., Bonus, S., \& Wright, E. (2004, January). Bridging the gap: A genre analysis of weblogs. Paper presented at the $37^{\text {th }}$ Annual Hawaii International Conference on System Sciences HICSS'04 Conference. Big Island, Hawaii. Retrieved April 2, 2009, from http://www.ics.uci.edu/ jpd/classes/ics234cw04/herring.pdf

Huffaker, D. (2005). Let them blog: Using weblogs to promote literacy in k-12 education. In L. T. W. Hin \& R. Subramaniam (Eds.), Handbook of research on literacy in technology at the K-12 level. Hershey, PA: Idea Group. Available http://www.davehuffaker.com/papers/Huffaker2005 LetThemBlog.pdf

Hurlburt, S. (2008). Defining tools for a new learning space: Writing and reading class blogs. MERLOT Journal of Online Learning and Teaching, 4(2), 182-189. Available http://jolt.merlot.org/vol4no2/hurlburt0608.pdf

Kang, M., Kim, J., \& Park, M. (2008). Investigating presence as a predictor of learning outcomes in elearning environment. In Proceedings of World Conference on Educational Multimedia, Hypermedia and Telecommunications 2008 (pp. 4175-4180). Chesapeake, VA: AACE.

Kerawalla, L., Minocha, S., Kirkuk, G., \& Conole, G. (2009). An empirically grounded framework to guide blogging in higher education. Journal of Computer Assisted Learning, 25(1), 31-42.

Kim, H. N. (2008). The phenomenon of blogs and theoretical model of blog use in educational contexts. Computers \& Education, 51, 1342-1352.

Koohang, A., Riley L., Smith, T., \& Schreurs, J. (2008). E-Learning and constructivism: From theory to application. Interdisciplinary Journal of E-Learning and Learning Objects, 5, 91-109. Available http://ijello.org/Volume5/IJELLOv5p091-109Koohang655.pdf

Korzenny, F. (1978). A theory of electronic propinquity: Mediated communications in organizations. Communication Research, 5, 3-24.

Ladyshewsky, R. K., \& Gardner, P. (2008). Peer assisted learning and blogging: A strategy to promote reflective practice during clinical fieldwork. Australasian Journal of Educational Technology, 24 (3), 241-257. Available http://www.ascilite.org.au/ajet/ajet24/ladyshewsky.html

Lankshear, C., \& Knobel, M. (2006, April). Blogging as participation: The active sociality of a new literacy. Paper presented at the American Educational Research Association, San Francisco. Retrieved April 2, 2009 from http://www.geocities.com/c.lankshear/bloggingparticipation.pdf

Levenberg, A., \& Gorsky, P. (2008). The effect of feedback on students' willingness to participate in educational blogs. In Y. Eshet, A. Caspi, \& N. Geri (Eds.), Proceedings of the Chais Conference on Instructional Technologies Research 2008: Learning in the Technological Era (pp. 242-245). Ra'anana, Israel: The Open University of Israel. [in Hebrew] Available http://telempub.openu.ac.il/users/chais/2008/after_noon/2_1.pdf

Lamshed, R., Berry, M., \& Armsrong, L. (2002). Blogs - Personal e-learning spaces. Binary Blue. Retrieved April 2, 2009 from http://www.binaryblue.com.au/docs/blogs.pdf 
Marlow, C. A. (2004, May). Audience, structure and authority in the weblog community. Paper presented at the International Communication Association Conference. New Orleans, LA. Retrieved April 2, 2009 from http://www.researchmethods.org/ICA2004.pdf

Marlow, C. A. (2006, March). Investment and attention in the weblog community. Proceedings of the AAAI Spring Symposium on Computational Approaches to Analysing Weblogs. Stanford University, California. Retrieved April 2, 2009 from http://alumni.media.mit.edu/ cameron/cv/pubs/2006-investmentand-attention-in-the-weblog-community.pdf

McKenzie, H. M. (2008). Why bother blogging? Motivations for adults in the United States to maintain a personal journal blog. MA Thesis. Retrieved April 2, 2009 from http://www.lib.ncsu.edu/theses/available/etd-03182008-224555/unrestricted/final.pdf

Mehrabian, A. (1969). Some referents and measures of nonverbal behavior. Behavior Research Methods and Instrumentation, 1(6), 205-207.

Mejias, U. (2005, October). A nomad's guide to learning and social software. The Knowledge Tree: An EJournal of Learning Innovation. Retrieved April 2, 2009 from http://knowledgetree.flexiblelearning.net.au/edition07/download/la mejias.pdf

Miura, A., \& Yamashita, K. (2007). Psychological and social influences on blog writing: An online survey of blog authors in Japan. Journal of Computer-Mediated Communication, 12(4). Retrieved April 2, 2009 from http://jcmc.indiana.edu/vol12/issue4/miura.html

Mishne, G., \& Glance, N. (2006, May). Leave a reply: An analysis of weblog comments. Paper presented at the 3rd Annual Workshop on the Weblogging Ecosystem (WWW06): Aggregation, Analysis and Dynamics. Edinburgh, UK. Retrieved April 2, 2009 from http://www.nielsenonline.com/downloads/us/buzz/wp_BlogCommentsStudy_Glance_2006.pdf

Nardi, B., Schiano, D., \& Gumbrecht, M. (2004). Blogging as a social activity, or would you let 900 million people read your diary? In Proceedings of the Conference on Computer-Supported Cooperative Work - CSCW (pp.222-231). New York: ACM. Available http://www.darrouzetnardi.net/bonnie/pdf/Nardi_blog_social_activity.pdf

Palmer, S., Holt, D., \& Bray, S. (2008, December). The learning outcomes of an online reflective journal in engineering. Paper presented at the $25^{\text {th }}$ ASCITE Conference: Hello! Where are you in the landscape of educational technology? Melbourne, Australia. Retrieved April 2, 2009 from http://www.ascilite.org.au/conferences/melbourne08/procs/palmer.pdf

Pinkman, K. (2005). Using blogs in the foreign language classroom: Encouraging learner independence. The JALT CALL Journal, 1(1), 12-24. Available http://www.jaltcall.org/journal/articles/1_1 Pinkman.pdf

Poling, C. (2005). Blog on: Building communication and collaboration among staff and students. Learning \& Leading with Technology, 32(6), 12-15.

Raban, D. R., \& Rabin, E. (in press). Statistical inference from power law distributed web-based social interactions. Internet Research. Retrieved April 2, 2009 from http://gsb.haifa.ac.il/ draban/home/6.pdf

Rafaeli, S., \& Ariel, Y. (2007). Assessing interactivity in computer-mediated research. In A. N. Joinson, K. Y. A. McKenna, T. Postmes, \& U. D. Rieps (Eds.), The Oxford handbook of internet psychology (pp. 71-88). Oxford: Oxford University Press.

Rourke, L., Anderson, T., Garrison, D. R., \& Archer, W. (1999). Assessing social presence in asynchronous, text-based computer conferencing. Journal of Distance Education, 14(3), 51-70.

Rovai, A. P., \& Barnum, K. T. (2003). On-line course effectiveness: An analysis of student interactions and perceptions of learning. Journal of Distance Education, 18(1), 57-73. Available http://cade.icaap.org/vol18.1/rovai.pdf

Schmidt, J. (2007). Blogging practices: An analytical framework. Journal of Computer-Mediated Communication, 12(4). Retrieved April 2, 2009 from http://jcmc.indiana.edu/vol12/issue4/schmidt.html 
Shea, P., Pickett, A. M., \& Pelt, W. E (2003). A follow-up investigation of teaching presence in the SUNY Learning Network. Journal of the Asynchronous Learning Network, 7(2). Retrieved April 2, 2009 from http://www.sloan-c.org/publications/jaln/v7n2/pdf/v7n2 shea.pdf

Ševelj, M. (2006, July). Weblogs as dynamic learning spaces. Paper presented at The Distance Education Association of New Zealand Biennial Conference. Auckland University of Technology (AUT), Auckland, New Zealand. Retrieved April 2, 2009 from http://grail.oise.utoronto.ca/blog/karaisko/files/2007/12/weblogs_dynamic_learning_spaces.pdf

Trevino, E. M. (2005). Blogger motivations: Power, pull, and positive feedback. Presented at Internet Research 6.0. Retrieved April 2, 2009 from http://blog.erickamenchen.net/MenchenBlogMotivations.pdf

Walther, J. B., \& Bazarova, N. N. (2008). Validation and application of electronic propinquity theory to computer-mediated communication in groups. Communication Research, 35, 622-645.

Warschauer, M., \& Grimes, D. (2007). Audience, authorship, and artifact: The emergent semiotics of web 2.0. Annual Review of Applied Linguistics, 27, 1-23.

Windham, C. (2007). Reflecting, writing, and responding: Reasons students blog. Educause Learning Initiative paper. Retrieved April 2, 2009 from https://www.educause.edu/ir/library/pdf/ELI8006C.pdf

Wishart, C., \& Guy, R. (2009). Analyzing responses, moves, and roles in online discussions. Interdisciplinary Journal of E-Learning and Learning Objects 5, 129-144. Available http://ijello.org/Volume5/IJELLOv5p129-144Wishart658.pdf

Witt, P. A., Wheeless, L. R., \& Allen, M. (2004). A meta-analytical review of the relationship between teacher immediacy and student learning. Communication Monographs, 71(2), 184-207.

Xie, Y., Ke, F., \& Sharma, P. (2008). The effect of peer feedback for blogging on college students' reflective learning processes. The Internet and High Education 11(1), 18-25.

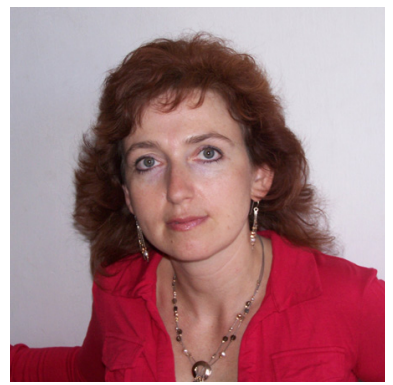

\section{Biographies}

Ina Blau is a faculty member in the Dept. of Education and Psychology at the Open University of Israel where she teaches graduate courses in the field of Educational Technologies. She is also a member of Chais Research Center for the Integration of Technology in Education. Her main research interests are social aspects of ecommunication, cyberpsychology, online learning communities, technology integration in synchronous and asynchronous teaching and learning.

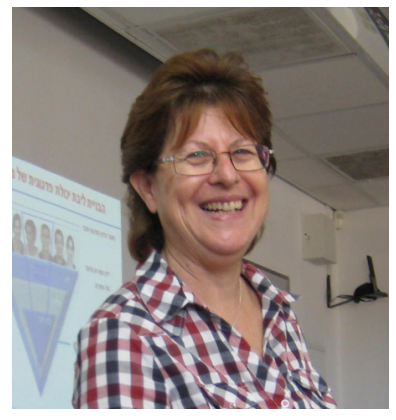

Dr. Nili Mor is a faculty member in the Dept. of Education and Psychology at the Open University of Israel, a faculty member in Levinsky college of education, and a coordinator of the program "ICT in Teacher Education" in Mofet Institute. Her main research interests are learning and teaching in technology rich environments, the intersection of theory, pedagogy and digital tools in postgraduate learning environment, ICT in teachers' professional development. 


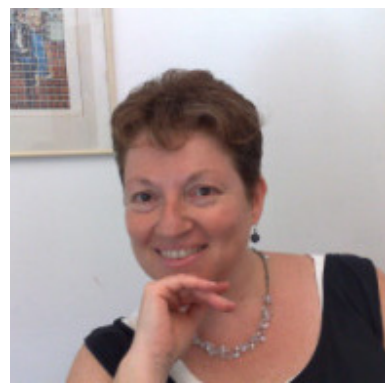

Tami Neuthal is an information specialist and instructional designer in the Center for Information Technology in Distance Education in the Open University of Israel. She also teaches Information Literacy in Bar-Ilan University. Her main interests are knowledge management in academia, social media as personal learning environments, and online collaboration. 